\title{
Progressive Museum Practice: John Dewey and Democracy
}

\section{Jeremiah Dyehouse}

George E. Hein, Progressive Museum Practice: John Dewey and Democracy. Walnut Creek, CA: Left Coast Press, 2012. 254 pp. ISBN 978-1-598-74480-4. \$39.95 (paperback).

In his fortieth anniversary commemoration of the Cooper Union Museum for the Arts and Decoration in 1937, John Dewey wrote confidently about the development of museums as educational institutions. As Dewey argued, "[o]ne of the most striking features of recent American culture has been the rapid growth of museums in all lines, artistic, commercial and industrial; of natural history, anthropology and antiquities." Dewey explained that it "has become generally recognized" that museums "occupy as necessary a place in popular education as do public libraries," arguing that "[v]ision of [museums'] educational function has kept pace with their material expansion." In general, Dewey contended, a "museum that is directed toward educational ends has to meet problems that are very different from those which existed when they were for the most part but collections of curious, interesting and possibly beautiful objects, or were collections of historical mementos."1

In a book published seventy-five years after Dewey's commemoration, George Hein argues that museum educators should rededicate themselves to progressive thinking about their institutions. His book, Progressive Museum Practice, describes an explicitly educational and democratic tradition for American museum institutions, and it places Dewey's philosophy at the center of this tradition. Hein emphasizes the educational and political dimensions of American museum practice from Charles Willson Peale's 18th century museum in Philadelphia to constructivist experiments in museum education in San Francisco's Exploratorium in the early 2000s. Reflecting on this practice, Hein argues that Dewey's philosophy, and particularly Dewey's thinking on education, can help contemporary museum educators to develop more progressive approaches to exhibition pedagogy.

Hein recommends Dewey's view on pedagogy as intimately related to politics. Acknowledging that "[i]nteractivity and experimentation are common in science museums and children's museums" and increasingly common in other kinds of museums, Hein describes the trend toward "doing" in museum spaces as exemplifying only “the immediate practical, pedagogic component of Dewey's educational 
agenda." "For Dewey," Hein argues, "the pedagogic aspects of progressive education were necessarily linked with the social goals of progressivism: the effort to improve economic and social conditions for the poor, acceptance of immigration as a potentially positive contribution to society, and recognition of the need for a communitarian spirit for building a strong democratic society." ${ }^{3}$ With this contrast in mind, Hein argues that museum exhibition designers have much to learn from Dewey as they seek to connect museum pedagogy with progressive social goals.

Given its purpose, its intended audience, and the complexity of the historical tradition it seeks to establish, Progressive Museum Practice's eight chapters are necessarily more oriented toward invoking, rather than examining, Dewey's philosophy. That said, those who specialize in study of Dewey's life and work will be attracted to Hein's chapters on "Educational Theory" (1), "John Dewey and Museums" (2), and "John Dewey and Albert Barnes" (5). Because it builds on Hein's study of Barnes and his involvement in the Barnes Foundation, and because it engages the secondary literature on Dewey, specialists will be especially attracted to the last of these chapters, which emphasizes the intellectual quality of Dewey and Barnes's friendship. In general, Hein writes as Barnes's apologist, defending this wealthy and irascible art educator against those who would dismiss him as a mere eccentric. With respect to Barnes's relationship with Dewey, Hein goes somewhat further, asserting Barnes's central influence on Dewey's thinking about aesthetics. Hein castigates philosophers (including Abraham Kaplan, Philip Jackson, and Sidney Hook) as well as art historians who have de-emphasized Dewey's intellectual debts to Barnes. Stressing the commitment to democratic education in the arts Barnes first demonstrated in his programs for his factory's workers, Hein argues that it was Barnes's experiments in art education that were especially valuable to Dewey. Referencing Dewey's reticence about aesthetics in the early decades of the twentieth century, Hein argues that "Barnes provided the key idea that permitted Dewey to include aesthetics within his general philosophy of experience: the view that aesthetic experiences are educative." In turn, Hein argues, Barnes learned from Dewey that "aesthetic experience should be encouraged as an intellectual activity that helps the learner solve life problems, to embrace a broader view of the world, and to improve both his (or her) own life and the lives of others."

Hein suggests that Dewey's involvement in the Barnes Foundation's instructional activities-for instance, in his role as its informal "director of education"satisfied any ambitions that Dewey might have had for museum teaching and learning. In making this argument, Hein glosses over what David Granger has called some of Foundation's "conspicuously unDeweyan" policies, including its emphasis on rigidly programmed, lecture-based education. ${ }^{6}$ Yet, Hein has a purpose in allying Dewey and Barnes so closely: together, Hein believes, Dewey and Barnes offer a specifically progressive contribution to continuing debates over museums' cultural functions. In Chapter 6, "Progressive Education in Art Museums," Hein 
discusses historically fierce disputes over art museums as oriented toward providing either aesthetic or educational kinds of experiences. Offering a brief examination of arguments offered on this issue by mid-20th century museum professionals, including Benjamin Ives Gilman, George Browne Goode, and Theodore Low, Hein subtly undermines the accounts of recent writers who emphasize "two polar ideologies that struggle for dominance in the art museum world."7 Instead, Hein asserts a vision for art museum practice he draws from Dewey's writings on art and Barnes's educational activities, where a visitor's aesthetic experience offers an opportunity for education that "contributes to personal and societal growth and development." Art museum experience, like museum experience more generally, is both aesthetic and educational.

The majority of Progressive Museum Practice attends to museum history, in which Hein highlights figures and events that exemplify a progressive American tradition. In keeping with this purpose, its chapters reflect, support, and contextualize the vision Hein extracts from Dewey and Barnes. In discussions of historical celebrities like Charles Willson Peale, as well as more obscure figures such as Louise Connolly, Anna Billings Gallup, and Laura Mary Bragg-three Progressive Era museum curators-Hein tells engaging stories about museum workers and their exhibitions. Hein's narrative details a flowering of progressive museum practice in the first decades of the twentieth century followed by a renewal of this practice in the 1960s. In keeping with this narrative, Hein describes the Anacostia Neighborhood Museum, the founding of the Exploratorium, and changing governance at the Boston Children's Museum in the 1960s as facets of a "re-emergence of progressive practice and the socio-political trends that combined progressive pedagogy with a democratic political goal."

In emphasizing Hein's audience, his purpose, and his principal contentions, this review does an injustice to his book, which is not actually as focused on argumentation as I have tended to suggest. In addition to making its points, Progressive Museum Practice also informs and entertains, arranging its historical materials to maximize their impact. Hein surveys the tradition in progressive museum practice that is his book's primary subject, sacrificing depth for breadth. But his many brief histories employ personal and situational details that develop for his account a broad appeal. In "John Dewey and Museums," for instance, Hein juxtaposes Dewey's personal correspondence with his educational writings, building up an intriguing picture of Dewey's thinking on museums. In particular, Hein connects Dewey's descriptions of his own museum visits, his treatment of museums in The School and Society, and his characterization of Hull House's Labor Museum. In the chapter, Hein summarizes Dewey to the effect that "museums should grow out of life experiences and be used to reflect back on life." "What we might call Hein's exhibition of Dewey's writings, however, goes beyond its summary, evoking Dewey's infectious enthusiasm for museum experience.

VOLUME $32(2) 2016$ 


\section{22 J. DyeHOUSE}

The leading idea that Hein draws from Dewey, that museums ought to be educational in the honorific sense of this term, is sure to be valuable to museum professionals. For other readers, however, Hein's account may take too much for granted regarding what a museum has been and what it might be. In this regard, Hein's and Dewey's comparisons of museums and libraries is suggestive: while it is still good policy to compare these two kinds of cultural institutions, such a comparison now also suggests the need to think about the librarian's books and the curator's exhibitions in more general kinds of ways. Hein himself might support inquiries into media access and display as potentially helpful for deepening the progressive vision of museum education he has sought to advance. Returning, perhaps, to the remarks on museums and libraries that Hein cited from The School and Society, we could consider anew Dewey's statement that "in the ideal school the art work might be that of the shops, passed through the alembic of library and museum and into action again."11 Today, such considerations involve complex questions about cultural, economic, and technological practices that increasingly blur the distinctions between previously distinct kinds of institutions. In its own way, Hein's book raises these kinds of questions, although it does not seek to answer them. That task remains for Hein's readers, who will be well served by his work toward a renewal of progressive museum practice.

\section{Notes}

1. LW 11:520-21.

2. George E. Hein, Progressive Museum Practice (Walnut Creek: Left Coast Press, 2012), 38 .

3. Ibid.

4. Ibid., 117.

5. Ibid., 143 .

6. Craig A. Cunningham, David Granger, Jane Fowler Morse, Barbara Stengel, and Terri Wilson, "Dewey, Women, and Weirdoes: Or, the Potential Rewards for Scholars Who Dialogue across Difference," Education and Culture 23, no. 2 (2007): 53.

7. Hein, Progressive Museum Practice, 130.

8. Ibid., 143 .

9. Ibid., 162.

10. Ibid., 46.

11. MW 1:53.

Jeremiah Dyehouse is an associate professor in the Department of Writing and Rhetoric at the University of Rhode Island. E-mail: jdyehouse@uri.edu 